\title{
EM MEMÓRIA \\ DO PROF. ANTONIO LÓPEZ GÓMEZ
}

SUZANNE DAVEAU ${ }^{1}$

Morreu em Janeiro de 2001 o nosso colega e amigo, Prof. Antonio López Gómez. Os geógrafos espanhóis já dedicaram três livros a este notável professor e investigador, além do que lhe tinham oferecido em 1989, aquando da sua jubilação. O facto é, em si, expressivo do apreço em que têm a sua obra e personalidade.

Parece oportuno que os geógrafos portugueses se associem calorosamente a esta homenagem. Antonio López Gómez era um homem discreto e modesto mas muito sabedor, e sempre prestável e acolhedor. Não podemos esquecer a ajuda que deu aos geógrafos de Lisboa, quando acedeu, em 1985, a fazer parte du júri que apreciou as primeiras teses de mestrado em Climatologia defendidas em Portugal, as de Catarina Ramos e José Ventura, dedicadas respectivamente à influência das situações anticiclónicas e das gotas de ar frio sobre o regime da precipitação em Portugal. Pessoalmente, constitui para mim lembrança inolvidável a visita dos surpreendentes, frescos e rumorosos jardins de Aranjuez, que descobri guiada por ele, e aos quais dedicaria, em 1988, o seu discurso de ingresso na Real Academia de la Historia.

Antonio López Gómez (1923-2001) faz parte da escassa geração de geógrafos espanhóis do imediato pós-guerra, que continua a considerar-se, antes de tudo, discípula do Professor Manuel de Terán (1904-1984). Esta geração, que conta também, entre outros, com os Professores Angel Cabo Alonso, Joaquín Bosque Maurel e Jesús García Fernández, foi obreira do rápido arrancar da Geografia moderna no país vizinho. Basta citar o facto de López Gómez ter dirigido 58 tesinas de licenciatura e 26 teses de doutoramento, para avaliar o seu papel na formação das gerações mais novas de geógrafos espanhóis. Não menos notável foi a sua função de animador das actividades, tanto do Instituto Juan Sebastián Elcano, que se manteve durante muito tempo praticamente o único centro de documentação geográfica disponível em Espanha, como da revista Estudios Geográficos, lançada em 1949 e que continua uma das importantes vozes de difusão da Geografia espanhola.

Nascido em Madrid e criado na época conturbada da Guerra Civil, López Gómez começou os estudos universitários em 1941, ensinou na Universidade de Valência de 1955 a 1969 e, a seguir, na Universidade Autónoma de Madrid, recentemente criada. Geógrafo "de andar e ver», que associava estreitamente «biblioteca e campo», ele foi

1 Investigadora do Centro de Estudos Geográficos. Universidade de Lisboa. E-mail: sdaveau@clix.pt 
sempre, e quis ser, o que os nossos colegas espanhóis chamam geógrafo «total» ou, ainda, «integral». Obrigado, nos anos 70, a escolher uma das três especializações então criadas e burocraticamente impostas, escolheu a "Geografia humana», e não, como todos então esperavam, a «Geografia física» ou a «Análise geográfica regional», mais limitativas. Esta escolha imposta não o impediu de continuar a estudar problemas referentes ao Clima e às Águas e a manter uma visão nunca teórica, mas concreta e enraizada regionalmente, dos factos que estudava, conforme tinha desde sempre praticado.

Los Paisajes del Agua chamou-se ao livro jubilar oferecido a D. Antonio em 1989; Historia, Clima y Paisaje intitulam-se os estudos geográficos a ele mais recentemente dedicados. Estes títulos tentam realçar os temas principais a que López Gómez dedicou a sua investigação, mas não conseguem abarcar nem a rica diversidade dos assuntos abordados em mais de 300 publicações, nem a segura coerência da sua visão da Geografia. Depois dos primeiros estudos, em que dominavam sobretudo os temas rurais, correspondentes às características da Espanha de meados do século XX, muitos dos trabalhos mais recentes - vários dos quais publicados postumamente - dizem respeito ao ramo em pleno desenvolvimento da Climatologia urbana ou à Geografia histórica. Entre estes últimos, sobressaem os que tratam do uso pelo homem das águas terrestres, fluviais e de regadio, e os consagrados à evolução do progressivo recenseamento geográfico e cartográfico da terra de Espanha. Os quatro livros de homenagem, e sobretudo o mais recente deles, cuidadosamente concebido e elaborado, constituem fontes de informação muito valiosa, não apenas sobre o homenageado e a sua notável obra, mas também, de modo mais amplo, sobre a evolução e as características da cada vez mais activa e diversificada escola espanhola de Geografia.

\section{OBRAS CITADAS}

1989 - Los Paisajes del Agua, Livro jubilar dedicado al profesor Antonio López Gómez. Universidade de Valência e Universidade de Alicante: 394p.

Este livro de homenagem caracteriza-se pela sua qualidade e coerência temática. Divide-se nas seguintes secções: 1. Precipitações. Escoamentos e balanço hídrico (4 artigos); 2. Regadios do Interior e do Litoral (16 artigos, que associam os aspectos da Geografia mais praticados pelo homenageado: vida rural, geografia da água e geografia histórica); 3. As necessidades urbanas e turísticas em recursos hídricos (6 artigos) e 4. Outros usos e problemas da água (4 artigos).

2002 - Estudios Geográficos, 63, 248/249, Madrid, Jul.-Dez: 365-796.

Contém um artigo de Joaquín Bosque Maurel sobre o homenageado (p. 367-383), um artigo inédito deste sobre Proyectos de traída de aguas a Madrid en el siglo XVIII y primera mitad del XIX» (p. 385-408) e 15 artigos dos seus colegas e discípulos. Contém ainda a recensão do livro de homenagem dedicado por F. Manero Miguel et al. ao Prof. Jesús García Fernández: Espacio Natural e Dinámicas Territoriales, Valladolid, 2001, 694p.

2003 - En Memoria de D. Antonio López Gómez. Conferencias invitadas al II Congresso de la Asociación Española de Climatología, Publicaciones de la AEC, Serie B, n. ${ }^{\circ}$ 2: $175 \mathrm{p}$.

Além do resumo das conferências proferidas por quatro climatólogos estrangeiros convidados ao Congresso, entre as quais a de Maria João Alcoforado sobre Alguns aspectos de 
Bioclimatologia. O clima e o organismo humano, o livro contém dois textos sobre a obra climatológica de López Gómez e a reedição de dois dos seus mais antigos artigos.

2004 - Historia, Clima y Paisaje, Universidade de Valência, Universidade Autónoma de Madrid e Universidade de Alicante: 567p.

O livro abre com a apresentação do homenageado por V. M. Rosselló e a da sua obra por Daniel Marías: as publicações próprias (325), as que dirigiu (90) e as que lhe foram até hoje dedicadas (31). Divide-se a seguir o livro em três partes: 1. Geografía histórica, com introdução de V. M. Rossalló, um artigo inédito de López Gómez sobre El método de Tomás López. e 12 artigos de colegas e discípulos; 2. Clima, com introdução de A. Gil, a reedição de um artigo de López Gómez e mais 10 contributos; 3. Los Paisajes y el Mundo Rural, com apresentação de F. Arroyo, um artigo póstumo de López Gómez sobre Las obras hidráulicas de Juan de Villanueva (1739-1811) y sua adecuación geográfica e 9 outros artigos, entre os quais gostaria de destacar o de Jesús García Fernández, El significado del médio ecológico en Geografía, pela luz que trás, não apenas sobre a obra do seu colega e amigo, mas sobre a evolução dos conceitos que orientaram, durante um século, o rápido desenvolver da Geografia espanhola.

2004 - Maurel, J. B. - Manuel de Terán (1904-1984), Estudios Geográficos, 65, 257, Out.Dez.: 589-594. 